\title{
OPINION
}

\section{Between Grexit and Utopia: EU Legal Theory in the Mirror of los indignados}

\author{
Luigi Corrias
}

After Syriza's recent victory in the Greek parliamentary elections, the EU is licking its wounds. Tsipras, the new Greek Prime Minister, has pledged to end the rule of austerity and wants to renegotiate with the so-called troika (European Commission, the European Central Bank (ECB) and International Monetary Fund (IMF)). Representatives of the Northern Member States stress that Greece is to honour all agreements and should repay every penny it received. In the meanwhile, the Podemos-party is eager to copy Syriza's success in the upcoming elections in Spain.

The developments in Greece and Spain should be understood against the background of the protest movements known as los indignados, the outraged. These protests started on 15 May 2011 in Spain. Just as in the Arab countries, the protests consisted in the occupation of major squares in such cities as Madrid and Barcelona. The protesters were angry about several things, including the way in which European austerity measures made their situation only worse and the general loss of autonomy over their lives. One demand, however, lies at the very core of the existence of los indignados: the reinvention of democracy under a horizontal and inclusive guise. ${ }^{1}$

On this topic, the protest movement and the EU seem, in the words of one commentator, 'lost in communication.'2 Reports regarding one rare meeting between a high official of the EU and four indignados suggest that the latter completely reject the democratic character of EU institutions. They argue that 'politicians don't represent us. ${ }^{3}$ Behind this statement lies a juxtaposition between representative democracy and its institutions on the one hand and 'real democracy' and participation on the other hand. ${ }^{4}$ The democratic challenge presented by los indignados thus cuts deeper than the EU's democratic deficit understood as an institutional problem. The latter issue might be solved by giving the European Parliament more competences and a greater influence on the political process. From the perspective of los indignados, however, this would only exacerbate the prob-

1 Thomas Decreus, 'Echte Democratie Nu! Over Directe Democratie en Representatie' [Real Democracy Now! On Direct Democracy and Representation], Krisis: Journal for Contemporary Philosophy 32(2) (2012): 32-42, at 32-33. http://www.krisis.eu/content/2012-2/krisis-2012-2-04decreus.pdf.

2 Michel Gauthier, 'EU, Indignados Lost in Communication' (2011) http://blogs.mediapart.fr/ edition/les-indignes-mouvement-15m/web/211011/eu-indignados-lost-communication.

3 Gauthier, 'EU, Indignados Lost in Communication.'

4 Decreus, 'Echte Democratie Nu! Over Directe Democratie en Representatie,' 33-35. 
lem, for reinforcing representative institutions cannot be the solution when 'the root of the problem lies in political representation' itself. ${ }^{5}$

Contemplating the legacy of los indignados, Marina Prentoulis and Lasse Thomassen point out two aspects. ${ }^{6}$ First, the primacy of the political vis-à-vis the economy. During the crisis it has been the economy (the logic of the financial market) that directed which politics to implement. As we know, in the EU context this meant the politics of austerity. Note that for the EU the relationship between the economy and politics and the primacy of the former over the latter is especially relevant because the EU has constituted itself as a polity with a common or internal market at its core. This is not only an economic but also a normative notion: the common market functions as the common good of the EU. ${ }^{7}$ Hence, the cry of those asking for real democracy ('we are not products in the hands of politicians and bankers' ${ }^{8}$ ), strikes at the very heart of what 'We, Europeans' are supposed to hold in common.

The second part of the legacy of los indignados is their call to rethink democratic politics. Apart from moving away from representative democracy towards participation and horizontality, there is another fundamental point at stake here: what is the proper place of (democratic) politics? The importance of this question becomes evident when one realizes that legal theory and political philosophy have always been fascinated by the question of space. To name just a few examples: the agora of Athens as the birthplace of democracy, the quest for a public space (Habermas) or space of appearance (Arendt), the qualification of democracy as a regime where the place of power is empty (Lefort) and the spatial understanding of nomos (Schmitt). Again, this question is critical for an EU which (in)famously suffers from a democratic deficit and the lack of a public sphere. Indeed, taking the streets and occupying the squares, los indignados might (again) have brought to light what has been called 'the Ortlosigkeit of EU democracy, the lack of a public stage for EU democracy.' 9

Where does this leave us as legal theorists studying the EU? One should not forget that law has always played a special role in the process of European integration. Already in 1986, law was said to be "both the object and agent of integra-

5 Marina Prentoulis and Lasse Thomassen, 'The Legacy of the Indignados' (2013) http://www. opendemocracy.net/can-europe-make-it/marina-prentoulis-lasse-thomassen/legacy-ofindignados.

6 Prentoulis and Thomassen, 'The Legacy of the Indignados.'

7 Hans Lindahl and Bert van Roermund, 'Law Without a State? On Representing the Common Market,' in The European Union and Its Order: The Legal Theory of European Integration, eds. Zenon Bankowski and Andrew Scott (Oxford and Malden, Ma.: Blackwell, 2000).

8 Manifesto of ¡Democracia real YA!, http://www.democraciarealya.es/manifiesto-comun/ manifesto-english/.

9 Rainer Nickel, 'From Integration through Law to Integration through Conflict,' in 'Integration through Law' Revisited: The Making of the European Polity, ed. Daniel Augenstein (Franham: Ashgate, 2012), 121-136, at 129. 
tion,' hence, we may speak of both integration of and integration through law. ${ }^{10}$ As an object, law may seem to be neutral; however, as an agent, it can no longer uphold such a claim. Law, and therefore lawyers, have played a crucial role in the building of the EU. As a consequence, EU lawyers are at least partially responsible for how the Union looks today. Let me be completely honest here: I was trained as an EU lawyer, as well. This piece is born from the wish to come to terms with what that means in an EU in crisis.

The EU legal order is also a (relatively) new object for legal theorists. Just as other examples of transnational law, like the law of the IMF, the World Bank and the WTO, EU law proves particularly challenging for a conceptual framework built for the nation-state. ${ }^{11}$ The EU gives food for thought, and the more theoretical and philosophical reflection we give it, the better the understanding of the EU might become. Inversely, the new EU order may also act as a catalyst for theoretical innovation. Thus, the relationship between EU law and legal theory is a dynamic one: 'the turn to theory has seen not just theory contributing to a keener understanding of the EU itself but rather (...) an iterative relationship in which the experimentalism of the EU legal order contributes to the theory building just as the infusion of theoretical perspectives builds a more sophisticated conception of that legal order. ${ }^{12}$ This iterative relationship between the theory and the practice of integration makes me moderately hopeful that our work as theorists may indeed make a difference. For the moment, I envision three main challenges ahead.

\section{The democratic challenge}

In a lecture on the European crisis, Jürgen Habermas recalls the 'passive consent' of the European citizens which was for a long time taken for granted by their politicians. ${ }^{13}$ Yet, the crisis in the EU has brought into the limelight the general Euroscepticism among citizens and the distance between Brussels and the national public spheres. The EU is faced with a Gordian knot: while a solution to the economic and Euro crisis asks for a full-blown political union ('more Europe'), the

10 Integration through Law, eds. Mauro Cappelleti, Monica Seccombe and Joseph Weiler (Berlin: Walter de Gruyter, 1986). See also: 'Integration through Law' Revisited: The Making of the European Polity, ed. Daniel Augenstein.

11 Julie Dickson and Pavlos Eleftheriadis, 'Introduction: The Puzzles of European Union Law,' in Philosophical Foundations of European Union Law, eds. Julie Dickson and Pavlos Eleftheriadis (Oxford: Oxford University Press, 2012), 1-22 at 2: 'Our established analytical tools, designed to characterize national institutions and structures, may prove too crude to account for the complexity of these new global arrangements. (...) The international appears to be a distinct domain and may thus require distinct concepts and tools in order adequately to understand it. The international polity which exhibits this distinctness at its clearest is the European Union.'

12 Jo Shaw, 'Plus ça change...,' in 'Integration through Law' Revisited: The Making of the European Polity, ed. Daniel Augenstein, 171-173 at 172.

13 Jürgen Habermas, 'Democracy, Solidarity and the European Crisis,' lecture on 26 April 2013 at the KU Leuven, http://www.kuleuven.be/communicatie/evenementen/evenementen/jurgenhabermas/en/democracy-solidarity-and-the-european-crisis. 
people seem generally tired of integration and strongly prefer 'less Europe.' Either way, the problem that remains is the democratic character of the next step. ${ }^{14}$

But something more might be wrong. That large numbers of Europeans seem to be fed up with European integration might well be one of the main drivers behind the rise of populist parties. The rise of anti-European populism should be situated in the dominant narrative of the No Demos-thesis - there is no such thing as a single European people and thus no subject who could give legitimacy to a European democracy - which continues to be the (mostly) implicit starting point, indeed the unquestioned horizon, of any discussion on democracy within the EU. It was, for instance, an important argument in the Dutch No-campaign in the elections on the European Constitution. ${ }^{15}$

Legal theorists ought to begin here by asking the question of the meaning or role of the people(s) in transnational democracy. The answer to such a question might then serve as the starting point for other, not less difficult questions, such as: how to take away the distrust in European institutions? What role can civil society play in this respect? How to build a truly European public sphere?

\section{The constitutional challenge}

While there is no need to try and reintroduce some constitutional document, one may argue that Europe's constitutional quest is far from over. In the sense that they voice a deep dissatisfaction with the current EU and cry out for 'Another Europe,' one could say that los indignados urge us to remember that quest. Legal theory thus far thoroughly researched EU constitutionalism. Notwithstanding the value of that work, we might still need more research into how constitutional change can come about after the failed constitutional project.

The failed European constitution left unanswered the constitutional question in the sense of 'a question of how best to conceive of the European Union as a political community; it is to ask how this community is constituted. More specifically, it is to ask what Europeans have in common and are willing to decide together in terms of the shape and substance of their legal, political and social system.' ${ }^{16}$ Asking this question means taking seriously European integration as a political project in which the struggle for power is institutionalized in a particular way. This means that at the European level the political choices made must be spelled out and opportunities for contestation must be provided. Until now, European integration, and indeed European law, have too often had a depoliticizing effect. ${ }^{17}$

14 On this issue, see also: Ben Crum, 'Saving the Euro at the Cost of Democracy?,' Journal of Common Market Studies 51(4) (2013): 614-630.

15 Arjen Nijeboer, 'Peoples' Vengeances: The Dutch Referendum,' European Constitutional Law Review 1(3) (2005): 393-405 at 404: 'An important argument of almost all no-campaigners was that there is no single "demos" in Europe, and a European democracy can therefore only be achieved in name and never in reality.'

16 Michael Wilkinson, 'Political Constitutionalism and the European Union,' The Modern Law Review, 76(2) (2013): 191-222 at 192.

17 Scott Veitch, 'Juridification, Integration and Depoliticization,' in 'Integration through Law' Revisited: The Making of the European Polity, ed. Daniel Augenstein, 85-97. 
Legal theorists should take up questions like: how to conceptualize constitutional politics beyond the nation-state? Who is (or are) the subjects of European constitutionalism? What does constitutional politics mean for the institutional balance within the Union? How can one avoid depoliticizing the project of European integration?

\section{The identity challenge}

There is a certain form of identity, political identity or 'the common,' which should be taken seriously by the legal theorist working on the EU. Habermas' lecture again proves to be an illuminating starting point to grasp what is at stake: he stresses the political character of obligations of solidarity which can rely only on 'political associations or shared political interests. ${ }^{\text {'18 }}$ Hence, the task in this respect is clear: 'What is required is solidarity instead, a cooperative effort from a shared political perspective to promote growth and competitiveness in the euro zone as a whole. ${ }^{19}$

This political perspective opens up such questions as: who do we mean when we say 'We, Europeans'? Whom do we exclude in saying 'We'? Thus, the identity challenge entails finding out what binds us together notwithstanding our differences in such a way that one may justly say 'We, Europeans.' As Habermas hints, this question is also pivotal in arriving at a concept of solidarity within the EU. As a political concept, the ties of solidarity and the corresponding demands can only exist between those who are part of a political 'We.'20 It is the task of legal theory to develop the conceptual framework to analyze and try to answer this kind of questions.

The challenges sketched above are surely not the only ones ahead. I do, however, believe that they mark the first steps which ought to be taken when one wants to help the EU escape its current predicament, caught somewhere between Grexit and Utopia.

18 Jürgen Habermas, 'Democracy, Solidarity and the European Crisis.'

19 Jürgen Habermas, 'Democracy, Solidarity and the European Crisis.'

20 In this sense, see also Andrea Sangiovanni, 'Solidarity in the European Union,' in Philosophical Foundations of European Union Law, eds. Julie Dickson and Pavlos Eleftheriadis (Oxford: Oxford University Press, 2012), 384-411. For a powerful defence of the necessity of the first-person plural perspective of a 'We' in politics, see Hans Lindahl, Fault Lines of Globalization: Legal Order and a Politics of A-Legality (Oxford: Oxford University Press, 2013) and Bert van Roermund, Legal Thought and Philosophy: What Legal Scholarship is About (Cheltenham: Edward Elgar Publishing, 2013). 